Book Review

What are the forms of crimes against the Unitary State of the Republic of Indonesia in the Penal Code? A Book Review of Kejahatan terhadap Negara Kesatuan Republik Indonesia, Adami Chazawi \& Ardi Ferdian, Sinar Grafika, 186 Pages, ISBN 978-979-007-771-3

Alviona Anggita Rante Lembang

Faculty of Law, Universitas Negeri Semarang, Indonesia

Email: alvionaanggita@students.unnes.ac.id

ORCID ID: https://orcid.org/0000-0003-3680-8100

\title{
DATA OF BOOK
}

Title

Author(s)

Language

Pages

Publisher

City of Publisher

ISBN
: Kejahatan terhadap Negara Kesatuan Republik Indonesia

: Adami Chazawi \& Ardi Ferdian

: Indonesia

: xii +186 pages

: Sinar Grafika

: East Jakarta, Indonesia

: 978-979-007-771-3

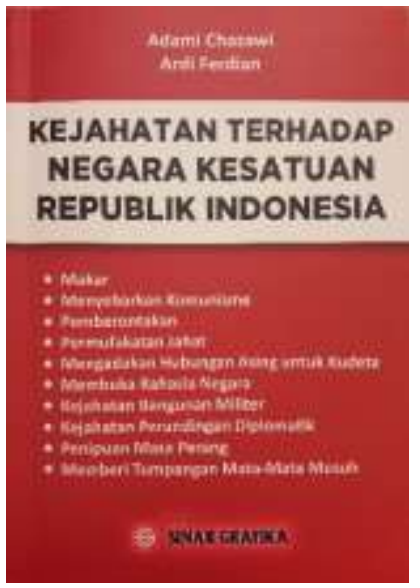

CRIMINAL Acts against State Security in Chapter I of Book II of the Penal Code (KUHP), are criminal groups that protect the legal interests regarding national safety and security of the Unitary State of the Republic of Indonesia. The forms of crimes against state security, which are protected by the provisions of Chapter I of Book II, are fundamental legal interests of the life process of the state in Indonesia. From the condition of preserving legal interests is an important factor in efforts to bring the Indonesian people to a 
comfortable and peaceful, justice, and prosperous life which is the goal of establishing the Unitary State of the Republic of Indonesia in 1945. Since the Indonesian nation's independence and sovereignty, there have been repeated incidents of attacks and rape in the interests of the life law of the nation and state of the Republic of Indonesia., such as the first PKI rebellion (MUSO in Madiun 1948); Kartosuwiryo in West Java (1949); PRRI in Sumatra (1958); PERMESTA in Sulawesi (1957); RMS in Maluku (1950); the second betrayal of the PKI (30-S / PKI); and there is still no end to interference with the population of Papua by the Free Papua Separatists.

Criminal Law in Chapter I of Book II of the Penal Code is a legal instrument as a preventive and repressive tool to fight and overcome rape / attacks on the interests of the national law, security and safety of the Republic of Indonesia.

\section{Evaluation}

In the Introduction, the authors first provide the basis for the distinction between crime and violation. The authors took the conclusions from the explanation of Memorie van Toelichting (MvT) of the Dutch WvS that the distribution is based on the fact that many people have committed acts that are basically reprehensible (against the law) and deserve to be convicted, even before they were stated by law. Meanwhile, there are new acts that are against the law and can be convicted after the Act states so.

The authors explained that the despicable trait of a criminal act of crime is not solely because it is contained in the law, but because the prohibited trait which contains an unlawful trait is inherent even before it is made in the formulation of the criminal act of the law. Meanwhile, the despicable trait of the criminal act of violation lies after it is contained in the law. The unlawful trait of a criminal act of violation arises only after it is contained in the law. Thus, the authors conclude that violation is lighter than crime. The authors' purpose in writing the distinction between crime and violation is actually achieved in this section. However, the authors do not convey the distinction directly and sentences that are used tend to be wordy so difficult to understand.

It is clear from the title, crime against the Unitary Republic of Indonesia is included in the category of crime. The authors then explained that crimes against the Unitary State of the Republic of Indonesia are regulated in Chapter I Book II of the Penal Code, starting from Article 104 to 
Article 129. The objects of crimes against the Unitary State of the Republic of Indonesia, cover various fields of state legal interests, for example the legal interest in safety and security the president and his deputy, the security of the government in carrying out its duties, the legal interest for the integrity of the national territory, the legal interest in state secrets, the legal interest in national defense and security against attacks from outside, and so on. In this section, the authors only rewritten what has been stated in the Penal Code.

The next chapter to the last chapter in this book then describes one by one about the forms of crime against the state. The forms of crime include:

1. Crime of treason;

By the authors, it is clearly explained that the types of treason crimes contained in Chapter I of Book II of the Penal Code consist of 3 (three) forms, namely 1) treason that attacks against legal interests for the security of the head of state or his representative (Article 104); 2) treason that attacks the legal interests of the territorial integrity of the Unitary Republic of Indonesia (Article 106); and 3) treason that attacks the legal interests of the establishment of state government (Article 107).

2. The crime of spreading the thoughts of Communism / MarxismLeninism;

In this chapter, the authors explains that in accordance with Chapter I of Book 2 of the Penal Code, crimes concerning and relating to Communism / Marxism-Leninism can be grouped into 3 (three) groups, namely 1) crimes concerning and in terms of prohibition of thoughts or understandings of Communism / Marxism-Leninism (Article 107a, Article 107c, Article 107d, and Article 107e); 2) crimes regarding declaring the desire to eliminate or replace the Pancasila State Foundation (Article 107b); and 3) sabotage crimes (Article 107f).

3. The crime of rebellion;

In this book, the authors write a qualification of rebellion consisting of 3 (three), namely: 1) people whose actions against the government with weapons; 2) people with the intention of opposing the Indonesian government invaded together with the mobs who were fighting the government with weapons; and 3) people who intend to oppose the government join the horde against the government with weapons. 
4. Conspiracy (Evil Agreement) to commit crimes Article 104, Article 106, Article 107 and Article 108;

The authors provides an understanding of conspiracy in accordance with Article 88, which is said to have a conpiracy, if two or more people have agreed to commit a crime.

5. The crime of entering into relations with a foreign country, person, or foreign entity to overthrow the government of the Republic of Indonesia;

In this chapter, the writer divides this crime into two parts, namely 1) the crime of having relations with a foreign country with the intention of moving it to hostile or war with Indonesia; and 2) the crime of engaging in relations with foreign persons or entities to overthrow the government of the Unitary State of the Republic of Indonesia.

6. Crime that reveals state secrets;

In accordance with Article 112 to Article 116, the authors rewrites that there are 5 forms of crime reveals state secrets, including 1) announcing letters, news or information that is confidential in the interest of the state; 2 ) the crime of revealing secrets regarding letters, maps, etc., that are related to the defense and security of the country which were carried out intentionally; 3) the crime of revealing state secrets regarding letters, maps and so on relating to national defense and security, which is committed unintentionally; 4) crime of reading or seeing letters or objects of state secrets; and 5) crime of conspiracy in the case of crimes Articles 113 and 115).

7. Crimes regarding military buildings and equipment;

This crime is also divided into several forms in the Penal Code, including: 1) crime without authority and deliberately approaching or entering military buildings, warships, entering restricted areas, hiding portraits of prohibited areas; 2) unauthorized crime deliberately makes collecting, etc. drawings, etc. related to military interests; 3) the crime of giving shelter to people who intend to know secret objects as formulated in Article 113; and 4) crimes Article 113, Article 115, Article 117, Article 118, and Article 119 which are accompanied by fraudulent acts of reason.

8. Crimes that harm the country in terms of diplomatic negotiations; 
This crime was formulated deliberately harming the country. The purpose of the formation of these crimes is to guarantee and protect the legal interests regarding state security and safety in terms of diplomatic relations.

9. Crimes that are not meant to help the enemy provide an enemy spy;

This crime was formulated in two forms, namely not with the intention of helping the enemy and providing a base for enemy spies and mobilizing or facilitating the desertion of members of the military serving for the country. In this crime, the perpetrators do not need to know that when carrying out an act there is a state of war, or because their actions can provide benefit to the enemy or harm the country.

10. Crimes during wartime are deceptive in handing over military supplies.

In this book, the authors write these two forms of crime as formulated in Article 127 paragraph (1) and paragraph (2) of the Penal Code, namely the act of deception in the supply of items of military necessity and deliberately letting the deception in the supply of goods of military necessity.

\section{Summary}

This book is more like a summary of the Penal Code on crimes against the Unitary State of the Republic of Indonesia which is more detailed by the authors so that not much can be commented on. When the Penal Code does not explain in detail the purpose of each article, the authors explain it in this book.

Seeing the way of elaborating each form of crime against the Unitary State of the Republic of Indonesia, namely by explaining one form in one chapter, the authors would like to invite the reader to find out more about crimes against the Unitary State of the Republic of Indonesia. Not only knowing the forms, but also knowing about the elements that must be fulfilled in order for an action to be categorized in the crime in question. By describing each form in one chapter, the writer succeeds in making a structured explanation.

However, this book is not suitable for readers who are very new entering the world of law because many words are not explained in detail by 
the authors so that it will be troublesome for readers to find the meaning of the word first. In addition, because the authors are based on the articles in the Penal Code, there are many articles included in this book. However, the authors do not write down the contents of these articles until again, the readers must search for the contents of these articles theirselves.

The writing styles that are used in this book are easy to understand but some are wordy and difficult to understand, especially for people who are still unfamiliar with the law.

This book is suitable for law students, legal practitioners, people who because of their position are directly or indirectly related to the issue of national defense and security, as well as observers of security and defense law, because it is hoped that after reading this book, readers will understand more about crimes against the Unitary State Republic of Indonesia, so that they can avoid it or even find this crime in the surrounding environment. 